UDC 378.1

DOI https://doi.org/10.32836/2310-9653-2018-2-64-69

T. O. Kostiuk, PhD in political science, Associate professor, Senior research fellow, Scientific Research Laboratory of Internationalisation of Higher Education Borys Grinchenko Kyiv University

\title{
UNIVERSITY SOCIAL RESPONSIBILITY AS A PART OF STATE CORPORATE RESPONSIBILITY
}

Every state has strategic fields including defense, national security, medicine and education. The last one through appropriate tools in the higher education makes impact to the other fields relating to the national security: it provides ideological, social, professional, patriotic and innovative background for the citizens.

One of the strongest attributes of higher education throughout the world is its ability to a permanent self-improvement, which enables to support the process of qualitative changes, optimally combine self-governing aspirations to new knowledge with the duty to act in favor of society. Today, the tendency is that universities become "engines" of the global knowledge economy, and for this reason, the principles of the relationship between higher education institutions and government, public and private organizations should change.

The results and consequences of traditional reforms at universities include: the emergence of a number of additional missions that can only be realized through the joint activity and interest of all parties in achieving the goal; new organizational obstacles and barriers; excessive administrative costs; increasingly unstable academic work; difficulties in financing fundamental research, and sometimes disputable changes in the quality assurance of higher education.

In addition, ongoing reforms at universities are often rigorous, decisions are made spontaneously, which impedes the stable and balanced development of higher education. It often happens that the national governments reduce the expenditures for the universities while the social weight and the role of university education should increase. Positive changes in this direction can be achieved through the conclusion of a new social contract between the government, society and universities called and regarded as the university social responsibility.

The main duties of higher education to society are to improve social, cultural, political, ethical and material well-being. Meeting these commitments requires government and business cooperation and their responsible attitude towards higher education, taking into account the right of universities to freedom and independence. In this case, higher education can really act as a "public critique and conscience".

Key words: higher education, social responsibility, public administration, Bologna process, Ukraine.

T. О. Костюк. Соціальна відповідальність вищеӧ освіти в контексті корпоративної відповідальності держнави

В Україні через затяжну кризу системи державного управління загалом та у сфері вищої освіти зокрема через лобіювання вузьких корпоративних інтересів і брак політичної волі університети виступають доволі відокремленим сектором, який декларує реформи і водночас залишається закритим для найкращих світових практик інновачійного розвитку та сощіалізащії. Першим кроком на шляху трансформацій у вищій освіті вважаємо гармонізацію державної та інститучійної політик щодо підвищення університетами рівня усвідомлення їх соиіальної відповідальності. За основу варто взяти успішний світовий досвід ефективної роботи університетів на благо суспільства. иес, Україна.

Ключові слова: вища освіта, соиіальна відповідальність, державне управління, Болонський про-

The problem setting in general. The discourse on university social responsibility (USR) extends from the end of the 20th century and is particularly active at the beginning of the 21 st century. This is partly due to the discussion of corporate social responsibility and its extrapolation to a modern university as a corporation, partly due to the growing role of higher education institutions (HEI) in the modern world, when the universities are admitted to be the social leaders who can offer solutions

(C) T. O. Kostiuk, 2018 
to solve the economic crisis, mitigate tensions between socio-ethnic or socio-cultural groups, provide opportunities for psychological rehabilitation, etc.

Generally, the USR can be defined as the recognition by the university of its obligations to internal and external stakeholders. Each university determines independently the USR degree that it strives to implement. However, the deep commitment to the USR will provide many benefits to the institution, such as: increasing the university's influence on society and promoting the solution of social problems; deepening public understanding of university research; strengthening cooperation with sectoral or state bodies; increasing the impact of university research on the social and cultural life of the local community; facilitating the participation of universities in policy development; potential support for the University to harmonize the policy and the funding.

A significant contribution to the development of USR was made by the Bologna Process. The Prague Communiqué (2001) proclaimed that as one of the tasks of the Bologna process is ensuring equal access to higher education, regardless of gender, ethnic origin, social status, etc. [7].

Social dimension to the Bologna process was introduced by the London Communiqué (2007). Recognizing that the student community should reflect the diversity and heterogeneity of the society, the London Communiqué simultaneously called on universities to properly provide services to students, to create flexible learning pathways and to increase, based on equal opportunities, the representation of student groups from different social strata and categories [8].

Growing role of intrenationalisation of higher education (IHE) made it enter into all the strategies in the field and got reflected in the documents. Thus, the Yerevan Communiqué (2015) explains that the strengthening of the social dimension of higher education is linked to gender balance, the expansion of access to higher education and the opportunities to complete education, including the opportunities for international mobility for students belonging to socially vulnerable groups of population; HEIs must respond positively to social and cultural diversity, promote multiculturalism, take into account demographic changes while developing curricula for the different categories of citizens. There are similar directions of USR activity: volunteering, philanthropy, transfer of knowledge and technologies, educational programs for children, youth, involvement of local community activists in decision making and decision taking processes [10].

Analysis of the latest research and publications. They estimate that for the first time the issue of social responsibility of universities was set up on the agenda of the World Declaration on Higher Education for the 21st Century adopted by the UNESCO Conference in 1998, Article 1 of which (among other missions) mentions the mission of higher education to promote sustainable development and improvement of society in general (the mission to contribute to sustainable development and the improvement of society as a whole) [9].

In 2009 under the auspices of UNESCO the World Conference on Higher Education "New Dynamics of Higher Education and Science for Social Change and Development" was held and its results were summarized in the Communiqué. There appeared unknown before section on "Social responsibility of higher education" which outlines the HEIs commitment to promote "sustainable development, peace, prosperity and the realization of human rights" [4]. Communiqué makes HEIs responsible for better understanding of the up-to-date problems, their social, economic, scientific and cultural dimensions; awareness of global challenges, including food security, climate change, water scarcity, the need for renewable energy sources and increased attention to health; urges HEIs to promote critical thinking and active civic stance, increase its interdisciplinary focus and promote the education of socially responsible citizens; expresses the hope that higher education will contribute to sustainable development, peace, prosperity, the realization of human rights, the protection of the values of democracy. The service of higher education to society is one of the leading topics of the Communiqué [4]. 
The Bologna Process started a new era in the topic development. Among other things it related USR to the lifelong learning. Since the European Higher Education Area, EHEA, was created in 2015, the European Union (EU) has funded at least two projects on the study and updating of university social responsibility. In the context of the formation of the EHEA, the first project "Comparative Research on the University of Social Responsibility in Europe and the Development of the Community Reference Framework" (EU - USR) was initiated within the framework of the EU Lifelong Learning Program and united 12 partners (mostly universities) from 5 EU member states in an effort to develop a USR framework and provided a comparative study of approaches and practices of social responsibility, with the example of 40 leading European universities. The project work was summarized in the Manifest, the Matrix (Framework Model), and the USR Standards.

The next project, ESPRIT: Enhancing the Social Characteristics and Public Responsibility of the Israeli Teaching through the HEI-Student Alliance was implemented by a consortium of 5 European and 6 Israeli partners under the TEMPUS Program and focused on the USR study of Israeli HEIs.

Compared to foreign universities which have already developed this area to high standards, for the domestic HEIs the USR issues are still rather unexplored. So, for the effective implementation of corporate social responsibility in domestic educational institutions it is expedient to study foreign experience and the possibilities of its implementation in Ukraine.

The research of corporate responsibility of leading educational institutions of the world was conducted by Ukrainian scientists, namely O. Hrishnova, S. Bekh, S. Kraievskii etc. They worked out different aspects of the USR, made a comparative analysis of the ways of USR realization in Ukrainian HEIs and marked the main vectors of the development [1;3]. O. Orzhel worked on the USR in the context of the University's leadership [5].

Formulating the goals of the article. The general goal for the paper is to follow the scientific discourse on the USR, its capacity building aspect, skills acquiring role and rating impact to understand pros and cons in the era of transnationalisation.

Presentation of the main material. Considering the dynamism of the modern global educational environment, increasing competition between universities for students and high-level teachers, researchers, ratings, resources, etc., HEIs are faced with the need maximum cooperate with the internal and external stakeholders to reach the goal and high results in their activity.

The main challenge of the era to be socially responsible is the ability to become innovative, strategic, and convincing in an institutional context to move to institutional development and provide high-level support and, in some cases, resources for success. The task is to fulfill an effective management of a functional unit that requires special technical skills (strategic planning, change management, project management, intercultural communication, negotiation skills and human resources management). The main roles identified for the USR strengthening are "innovator", "broker", "monitor", "coordinator", and "director". Finally, there is also common view on the key steps needed to improve the skills and capabilities of leaders and managers. For all groups, there is a strong need for innovation and entrepreneurial / strategic skills to meet the ever-changing external and internal challenges [6].

In this context the universities must clearly realize their mission in augmenting USR: leadership serving and the capacity building. Contemporary requirements to the university graduates on the one hand presume different skills and abilities of a universal worker and on the other - to transform the HEI into a factory with a visible dominance of so called "soft" skills.

There are two types of skills the universities provide with: hard skills and soft skills. The hard skills - these are all skills that are directly related to the profession and the activities in which a person is engaged. For example, if you are a programmer, your hard skills are all connected with programming. For a screenwriter, hard skills are his scripting, writing and composing skills. For a 
factory worker, hard skills are operational and technical activities. The soft skills are not connected with the profession, but with the communications and skills necessary for successful work in their field, team, and as a team - with other people. The widest soft skills block is communication skills. The common communication skills that everyone needs are the ability to talk, argue their position, provide counter-arguments, ask the right or controversial questions, give feedback, and so on. But there are somehow concentrated communication skills - for example, communication in sales, management, ability to negotiate. There is also a large block of other soft skills of various kinds: time management, personal finance management, work with information, goal setting, etc.

If to talk about the formation of skills, there is a classical scheme "knowledge - capability skill". Knowledge is all that everyone can learn from books, lectures, seminars, master classes. This is some information, a set of conceptual models and algorithms. Capability is a transitional moment when we try to put the received knowledge into practice, and it turns out with different success. Skill is embedding skills in automated behavioral modules and patterns. An adult does not need to think about how to tie the laces, he does it automatically.

Every person develops in three main areas: professional competencies (the "hard" skills); personal competencies (how we make decisions, how we organize our activities, how we build the logic of our activities, how we deal with time, critical thinking); social competencies (communicative skills, conflict management skills, ability to work in teams / teams, as well as knowledge of human nature and human behavior). Two last belong to "soft" skills.

IHE favors the development of both types of skills. Academic mobility helps to get professional, personal and social skills, but the credit academic mobility contributes more to development of soft skills.

There is a common view that formal graduate-level courses focusing on leadership and management with a special emphasis on internationalization can be useful and seek a higher level of responsibility. However, less formal training at all levels is perceived as more relevant and clearly needed [6].

Short courses / credit academic mobility / seminars aimed at precisely setting up or enabling the acquisition of certain technical skills (such as change management, project management, adaptivity, communication / intercultural talks, financial management, fundraising skills, innovation skills) are of high importance. In addition, other less formal training involving peer education, networking, mentoring, or coaching and affiliation are also valuable. Individual meetings / expert seminars with leading international leaders on specific topics (e.g. good practice examples and thematic case studies on key priority issues) and individual peer education with colleagues in institutions within the same country by the internationalized curriculum or abroad provide unique possibilities to bring up necessary skills. Thematic one-way seminars and workshops are useful for group work, team building, social responsibilities at different levels, focusing on understanding the changing national and global contexts of higher education and the role of internationalization in them, drivers and trends in internationalization and the diversity of institutional responses to internationalization and the role of international leadership in education (at all levels).

The logical question is how do students master these skills and refine them to practice during training? Every student while learning, is gradually developing his own "soft skills" in different ways, but particularly when communicating with colleagues, faculty, and auxiliary staff. Much more effective it can be caught through IHE, either through outbound form or "at home" with internationalized curricula, making students be actively involved into multicultural environment, participation of the student in various circles, unions, public associations, scientific societies, student selfgovernment, etc. This activity in various student and youth initiatives helps to improve communicative skills and take responsibility for decisions. 
Conclusions from this study and prospects for further exploration in this direction. The USR is an important attribute and mission of all modern HEIs. It contributes much to the external (strengthening international economic ties of the region and country with partner countries, increasing investment attractiveness) and internal (strengthening the reputation of the university levels, increasing the brand value) levels of the university promotion.

The USR is usually applied in close cooperation of the university with business, research centers, society, educational institutions and authorities. The USR can also be realized through the IHE mechanisms like the training of foreign citizens, foreign professors' guest lectures, foreign internships, student exchanges, international research, conferences, grants, because they actively help to promote university, to make it high-ranked and socially responsible.

Generally the HEI is responsible for the transfer of knowledge, skills from generation to generation to enable society support actual existence and development; for the development of science and the main trends of the development of society; for the training of high quality specialists; for preparing the elite of society; for the erosion of social barriers in society: the higher education usually serves as a prerequisite for increasing social status, vertical movement from one social stratum to another.

Ukrainian HEIs should explore the world experience of USR implementation, as it is the best way to overcome the acutest problems of the society and the societal challenges. The youth is the most adaptive and flexible stratum, it must remain free of blocks, borders and ideological superstitions.

Further exploration of the theme is supposed to identify other institutional, legal and organizational peculiarities and make up a list of recommendations for the Ukrainian HEIs for a successful implementation of the best practices of augmenting USR.

\section{References:}

1. Грішнова О.А., Бех С.В. Соціальна відповідальність університетів України: порівняльний аналіз та основні напрями розвитку. Вісник Київського національного університету ім. Тараса Шевченка. Серія: Економіка. 2014. № 158. С. 11-17.

2. Про вищу освіту: Закон України від 01 липня 2014 р. № 1556-VII / Офіційний вебсайт Верховної Ради України. URL: http://zakon4.rada.gov. ua/laws/show/1556-18.

3. Заярна Н.М., Краєвський С.Б. Використання трудового потенціалу студентів як один iз шляхів підвищення професійного рівня молодих спеціалістів. Науковий вісник НЛТУ України. 2010. № 20.13. С. 348-351.

4. Нова динаміка вищої освіти і науки для соціальної зміни і розвитку: всесвітня конференція з вищої освіти. ЮНЕСКО, Париж, 5-8 липня 2009 р. URL: http://zakon2.rada.gov.ua/ laws/show/952 011 .

5. Оржель О. Університетська соціальна відповідальність у контексті університетського лідерства: навч. посіб. К.: ДП «НВЦ «Пріоритети», 2017. 40 с.

6. Kostiuk T. Internationalisation of higher education in acquiring the "soft" and the "hard" skills: what is more?: Матеріали міжнародної науково-практичної конференції «UniversumView 2» (м. Суми, 17 жовтня 2018 р.). Вінниця: ТОВ «Нілан-ЛТД», 2018. 776 с.

7. Towards the European Higher Education Area. Communiqué of the meeting of European Ministers in charge of Higher Education in Prague on May 19th, 2001. URL: http://media.ehea.info/ file/2001_Prague/44/2/2001_Prague_Communique_English_553442.pdf.

8. Towards the European Higher Education Area: responding to challenges in a globalised world. London Communiqué of May 18th, 2007. URL: http://media.ehea.info/file/2007_London/69/7/2007_London_Communique_English_588697.pdf. 
9. World Conference on Higher Education: Higher Education in the Twenty-first Century. Vision and Action. UNESCO, Paris, October, 5-9, 1998. URL: http://unesdoc.Unesco.org/images/0011/001163/116345E.pdf.

10. Yerevan Communiqué. Ministerial conference of May, 14-15, 2015. URL: http:// media.ehea.info/file/2015_Yerevan/70/7/YerevanCommuniqueFinal_613707.pdf.

\section{References:}

1. Hrishnova O.A., Bekh S.V. Sotsial'na vidpovidal'nist' universytetiv Ukraiiny: porivnyal'nyi analiz ta osnovni napriamy rozvytku. Visnyk Kyiivs'koho natsional'noho universytetu im. Tarasa Shevchenka. Seriia: Ekonomika. 2014. № 158. S. 11-17.

2. Pro vyshchu osvitu: Zakon Ukrayiny vid 01.07.2014 № 1556-VII (Law of Ukraine “On higher education”. № 1556-VII, 2014). URL: http://zakon4.rada.gov.ua/laws/ show/1556-18.

3. Zaiarna N.M., Kraievs'kyi S.B. Vykorystannia trudovoho potentsialu studentiv yak odyn iz shliakhiv pidvyshchennia profesiynoho rivnia molodykh spetsialistiv. Naukovyi visnyk NLTU Ukraiiny. 2010. № 20.13. S. 348-351.

4. Nova dynamika vyshchoii osvity i nauky dlia sotsial'noii zminy i rozvytku: vsesvitnia konferentsiia z vyshchoii osvity. UNESCO, Paryzh, 5-8 lypnia, 2009 roku. URL: http:// zakon2.rada.gov.ua/lavs/show/952_011

5. Orzhel' O. Universytets'ka sotsial'na vidpovidal'nist' u konteksti universytets'koho liderstva: navch. posib. K.: DP "NVTS "Priorytety", 2017. $40 \mathrm{~s}$.

6. Kostiuk T. Internationalisation of higher education in acquiring the "soft" and the "hard" skills: what is more?: materialy mizhnarodnoii naukovo-praktychnoii konferentsiii "Universum View 2" (Sumy, October 17, 2018). Vinnytsia: TOV "Nilan-LTD”, 2018. 776 s.

7. Towards the European Higher Education Area. Communiqué of the meeting of European Ministers in charge of Higher Education in Prague on May 19th, 2001. URL: http://media.ehea.info/ file/2001_Prague/44/2/2001_Prague_Communique_English_553442.pdf.

8. Towards the European Higher Education Area: responding to challenges in a globalised world. London Communiqué of May 18th, 2007. URL: http://media.ehea.info/file/2007_London/69/7/2007_London_Communique_English_588697.pdf.

9. World Conference on Higher Education: Higher Education in the Twenty-first Century. Vision and Action. UNESCO, Paris, October, 5-9, 1998. URL: http://unesdoc. Unesco.org/images/0011/001163/116345E.pdf.

10. Yerevan Communiqué. Ministerial conference of May, 14-15, 2015. URL: http:// media.ehea.info/file/2015_Yerevan/70/7/YerevanCommuniqueFinal_613707.pdf. 